\title{
IMPLEMENTASI KEBIJAKAN PELAYANAN ADMINISTRASI TERPADU KECAMATAN DI KECAMATAN KLUET UTARA KABUPATEN ACEH SELATAN PROVINSI ACEH
}

\author{
Oleh \\ Aris Maulida Monkuba ${ }^{1}$, \\ Kusworo $^{2}$, Yudi Rusfiana ${ }^{3}$ \\ 1) Pemerintah Kabupaten Aceh Selatan \\ Program Magister Terapan Studi Pemerintahan Daerah Institut Pemerintahan Dalam Negeri \\ amonkuba@gmail.com \\ ${ }^{2,3)}$ Institut Pemerintahan Dalam Negeri
}

\begin{abstract}
$B^{a}$ ased on the Regulation of the Minister of Home Affairs Number 4 of 2010 concerning Guidelines for Integrated District Administration Services. In accordance with the regulation, Kluet Utara District, South Aceh Regency uses the PATEN program in terms of public services.

This study uses descriptive qualitative research methods using the theory of policy implementation according to Edwards III and SWOT analysis and litmus test. Then data collection in this study through observation, interviews and documentation with data reduction analysis techniques, data displai and verification.

The results of the study concluded that the implementation of the Integrated District Administration Service Policy in Kluet Utara District, South Aceh Regency has not been implemented properly because 1) there is still a lack of communication in the implementation of patents, it seems that not all people have received socialization 2) lack of resource competence because there are still some employees who have not participating in training 3) lack of facilities and infrastructure and in the aspect of bureaucratic structure it can be said that it is good because of the existence of SOP and clear fragmentation Then there are several internal factors that influence the implementation of PATEN policies in the North Kluet sub-district, namely regulations, commitment, coordination, facilities and infrastructure, budget and apparatus resources and several external factors, namely support and cooperation, participation and cooperation, participation of village heads, technological developments and information. Then there are several strategic proposals based on the SWOT analysis and litmus test, including: 1) increasing the commitment of the District Government in implementing PATEN, 2) optimizing the functions of existing employees to carry out PATEN tasks, 3) improving the facilities and infrastructure for implementing Integrated District Administration Services, and 4) implementing a pick-up program to solve the problem of the distance between the North Kluet District government center from several villages.
\end{abstract}

Keywords: public service, policy implementation, PATEN. 


\section{Abstrak}

B erdasarkan Peraturan Menteri Dalam Negeri Nomor 4 Tahun 2010 tentang Pedoman Pelayanan Administrasi Terpadu Kecamatan. Sesuai dengan peraturan tersebut Kecamatan Kluet Utara Kabupaten Aceh Selatan menggunakan program PATEN dalam hal pelayanan publiknya.

Penelitian ini menggunakan metode penelitian kualitatif deskriptif dengan menggunakan teori Implementasi Kebijakan menurut Edwards III dan analisis SWOT serta litmus test. Kemudian pengumpulan data dalam penelitian ini melalui observasi, wawancara dan dokumentasi dengan teknik analisis reduksi data, displai data dan verification.

Hasil penelitian menyimpulkan bahwa Implementasi Kebijakan Pelayanan Administrasi Terpadu Kecamatan di Kecamatan Kluet Utara Kabupaten Aceh Selatan belum dapat implementasikan dengan baik karena 1) masih kurangnya komunikasi dalam pelaksanaan paten terlihat belum semua masyarakat mendapatkan sosialisasi 2) kurangnya kompetensi sumber daya dikarenakan masih terdapat beberapa pegawai yang belum mengikuti pelatihan 3) kurangnya sarana dan prasarana dan pada aspek struktur birokrasi sudah dapat dikatakan baik dilihat adanya SOP dan Fragmentasi yang jelas. Kemudian terdapat beberapa faktor internal yang memengaruhi implementasi kebijakan PATEN di kecamatan Kluet Utara, yaitu peraturan, komitmen, koordinasi, sarana dan prasarana, anggaran dan sumber daya aparatur dan beberapa faktor eksternal, yaitu dukungan dan kerja sama, partisipasi dan kerja sama, partisipasi kepala desa, perkembangan teknologi dan informasi. kemudian terdapat beberapa usulan strategi berdasarkan analisis SWOT dan litmus test antara lain: 1) meningkatkan komitmen Pemerintah Kecamatan dalam melaksanakan PATEN, 2)mengoptimalkan fungsi pegawai yang ada untuk melaksanakan tugas PATEN, 3) meningkatkan sarana dan prasarana pelaksanaan Pelayanan Administrasi Terpadu Kecamatan, serta 4) melaksanakan program jemput bola untuk mengatasi permasalahan jauhnya letak pusat pemerintahan Kecamatan Kluet Utara dari beberapa desa.

Kata kunci: pelayanan publik, implementasi kebijakan, PATEN.

\section{PENDAHULUAN}

$\mathrm{T}$ erbitnya Undang-Undang Nomor 9 Tahun 2015 yang merupakan perubahan kedua atas UndangUndang Nomor 23 Tahun 2014 tentang Pemerintahan Daerah secara ekplicit mendorong pemerintah daerah untuk dapat memberikan pelayanan yang baik kepada masyarakat. Sehingga dapat berimplikasi kepada peningkatan kualitas pelayanan itu sendiri. hal ini sebagaimana dinyatakan dalam Pasal 2 ayat (3) Undang-Undang Nomor 23 Tahun 2014 bahwa,"pemerintah daerah sebagaimana dimaksud pada ayat (2) menjalankan otonomi seluasluasnya, kecuali urusan pemerintahan yang menjadi urusan pemerintah, dengan tujuan untuk meningkatkan kesejahteraan masyarakat, pelayanan umum dan daya saing daerah".

Dakam rangka memenuhi kebutuhan masyarakat untuk mendapatkan pelayanan yangmudah,cepatdantepatuntukmenunjang kelancaran proses pelayanan ditingkat kecamatan maka pemerintah menggulirkan program Pelayanan Administrasi Terpadu Kecamatan (PATEN) dengan dikeluarkannya Peraturan Menteri Dalam Negeri Nomor 4 Tahun 2010 tentang Pedoman Pelayanan Administrasi Terpadu Kecamatan. Keputusan Bupati Aceh Selatan No. 445 Tahun 2014 tanggal 7 Oktober tentang penetapan kecamatan sebagai penyelenggara PATEN dalam Kabupaten Aceh Selatan Tahun 2014 yang mana pada ruang lingkup program Pelayanan Administrasi Terpadu Kecamatan 
(PATEN) ini meliputi pelayanan bidang perizinan dan pelayanan non perizinan. Pelayanan Administrasi Terpadu Kecamatan (PATEN) dimaksudkan untuk mewujudkan kecamatan sebagai pusat pelayanan masyarakat dan menjadi simpul pelayanan bagi Badan, Dinas atau Kantor pelayanan terpadu di Kabupaten/Kota. Dengan adanya Pelayanan Administrasi Terpadu Kecamatan (PATEN) diharapkan dapat meningkatkan kualitas dan mendekatkan pelayanan kepada masyarakat.

Mengenai pelayanan, Kecamatan menjadi posisi sentral ujung tombak pemerintahan Kabupaten/Kota dalam penyelenggaraan tugas dan fungsi pelayanan. Untuk itu aparatur Kecamatan dituntut untuk mengoptimalkan pemberian pelayanan kepada masyarakat serta memiliki aparat yang mempunyai kemampuan teknis dan manajerial, profesional dan berkompetensi di bidangnya. Adapun Sumber Daya Manusia (SDM) dalam hal ini pegawai yang terdapat di Sekretariat Kecamatan Kluet sebagai berikut.

Tabel 1 Daftar Pegawai Kecamatan Kluet Utara

\begin{tabular}{cll}
\hline No. & $\begin{array}{c}\text { Jenjang } \\
\text { Pendidikan }\end{array}$ & Jumlah \\
\hline 1. & SLTP & - \\
2 & SLTA & 28 \\
3 & D-II & - \\
4 & D-III & 5 \\
5 & S-1/D-IV & 8 \\
6 & S-2 & - \\
7 & S-3 & - \\
\hline Jumlah & 41 \\
\hline
\end{tabular}

Sumber: Sekretariat Kecamatan Kluet Utara 2019

Tabel di atas memperlihatkan bahwa salah satu permasalahan yang terdapat di dalam implementasi kebijakan Pelayanan Administrasi Terpadu Kecamatan (PATEN) khususnya di Kecamatan Kluet Utara Kabupaten Aceh Selatan dalam memberikan pelayanan kepada masyarakat guna menciptakan pelayanan prima yakni keterbatasan sumber daya manusia baik baik secara kualitas

Selain itu untuk terselenggaranya PATEN secara baik dibutuhkan sarana dan prasarana yang memadai. Hal ini merupakan salah satu persyaratan teknis dalam Peraturan Menteri Dalam Negeri Nomor 4 Tahun 2010 tentang Pedoman Pelayanan Administrasi Terpadu Kecamatan yang tersebut pada Pasal 9 huruf a. Adapun sarana prasarana yang dimiliki oleh Sekretariat Kecamatan Kluet dalam proses pemberian pelayanan PATEN terdapat pada tabel di bawah ini:

Tabel 2 Daftar Inventaris Ruangan PATEN

\begin{tabular}{|c|c|c|c|c|c|}
\hline \multirow{2}{*}{ No } & \multirow{2}{*}{$\begin{array}{c}\text { Nama/Jenis } \\
\text { Barang }\end{array}$} & \multirow{2}{*}{$\begin{array}{l}\text { Jumlah } \\
\text { Barang }\end{array}$} & \multicolumn{3}{|c|}{ Keadaan Barang } \\
\hline & & & B & KB & $\mathbf{R}$ \\
\hline 1. & Komputer & 1 & & $\sqrt{ }$ & \\
\hline 2. & Printer & 1 & & $\sqrt{ }$ & \\
\hline 3. & $\begin{array}{l}\text { K u r s i } \\
\text { Petugas }\end{array}$ & 4 & $\sqrt{ }$ & & \\
\hline 4. & $\begin{array}{l}M \text { e j a } \\
\text { Petugas }\end{array}$ & 4 & $\sqrt{ }$ & & \\
\hline 5. & $\begin{array}{l}\mathrm{K} \mathrm{u} \mathrm{r} \mathrm{s} \mathrm{i} \\
\text { tunggu }\end{array}$ & 2 & $\sqrt{ }$ & & \\
\hline 6. & $\begin{array}{l}\mathrm{L} \text { e } \mathrm{m} \text { a } \mathrm{r} \text { i } \\
\text { arsip }\end{array}$ & 1 & & $\sqrt{ }$ & \\
\hline
\end{tabular}

Keterangan: $\mathrm{B}$ = baik, $\mathrm{KB}=$ kurang baik, $\mathrm{R}=$ rusak

Sumber: Sekretariat Kecamatan Kluet 2019

Pada tabel di atas terlihat bahwa masih kurangnya sarana dan prasarana dalam memberikan Pelayanan Administrasi Terpadu Kecamatan (PATEN) khususnya di Kecamatan Kluet Kabupaten Aceh Selatan dalam memberikan pelayanan kepada masyarakat guna menciptakan kenyamanan dalam pelayanan.

Selain itu, untuk menjalankan program Pelayanan Administrasi Terpadu Kecamatan (PATEN) Pemerintah Kabupaten Aceh Selatan menganggarkan dana pada tiap Kecamatan sebesar Rp20.500.000,-/per tahun yang dialokasikan dalam Dokumen Pelaksanaan 
Anggaran (DPA) pada tiap-tiap Sekretariat Kecamatan. Anggaran tersebut dirasa kurang mengingat banyaknya pelayanan serta kebutuhan dalam memenuhi pelayanan yang diberikan untuk kepada masyarakat.

Berbagai upaya yang telah dilakukan Pemerintah Kecamatan Kluet Kabupaten Aceh Selatan untuk menghasilkan pelayanan yang lebih cepat, tepat dan memenuhi kebutuhan masyarakat. Namun upaya-upaya yang dilakukan oleh Pemerintah Kecamatan Kluet Kabupaten Aceh Selatan belum optimal. Salah satu indikator yang dapat dilihat adalah masih banyaknya keluhan masyarakat dalam pelayanan yang diberikan oleh aparatur Kecamatan. Melihat keluhan yang sering terjadi pada masyarakat dikarenakan tidak optimalnya kinerja aparatur Kecamatan dalam memberikan pelayanan kepada masyarakat. Kurang optimalnya kinerja aparatur Kecamatan sehingga berimbas pada kualitas pelayanan disebabkan oleh beberapa faktor di antaranya: kurangnya pemahaman aparatur Kecamatan Kluet Utara dalam memberikan pelayanan kepada masyarakat, masih minimnya sarana dan prasarana yang memberikan dampak yang cukup besar terhadap kegiatan pelayanan, terbatasnya jumlah sumber daya aparatur Kecamatan yang bertugas memberikan pelayanan kepada masyarakat, terbatasnya dana yang tersedia dari APBK untuk penyelenggaraan program Pelayanan Administrasi Terpadu Kecamatan (PATEN) sehingga menjadi kurang optimal. Selain itu masih sedikitnya masyarakat yang mengetahui program Pelayanan Administrasi Terpadu Kecamatan (PATEN) ini yang terdapat di Kecamatan Kluet Kabupaten Aceh Selatan Provinsi Aceh serta Standar Pelaksanaan Prosedur (SOP) yang belum maksimal diterapkan oleh aparatur Kecamatan.

\section{Identifikasi masalah}

Melihat uraian yang dikemukakan pada latar belakang permasalahan di atas, maka penulis, mengidentifikasi masalah-masalah yang terjadi antara lain sebagai berikut.

1. Masih kurangnya pemahaman aparatur Kecamatan Kluet Utara dalam memberikan pelayanan kepada masyarakat khususnya Pelayanan Administrasi Terpadu Kecamatan (PATEN).

2. Masih minimnya sarana dan prasarana yang berdampak pada pemberian pelayanan terhadap kegiatan Pelayanan Administrasi Terpadu Kecamatan (PATEN)

3. Terbatasnya jumlah sumber daya aparatur Kecamatan yang bertugas memberikan Pelayanan Administrasi Terpadu Kecamatan (PATEN).

4. Terbatasnya dana yang tersedia dari APBK untuk penyelenggaraan program Pelayanan Administrasi Terpadu Kecamatan (PATEN).

5. Masih sedikitnya masyarakat yang mengetahui program Pelayanan Administrasi Terpadu Kecamatan (PATEN) yang terdapat di Kecamatan Kluet Kabupaten Aceh.

\section{Perumusan Masalah}

Dari uraian pembatasan masalah di atas, peneliti merumuskan masalah sebagai berikut.

1. Bagaimana Implementasi Kebijakan Pelayanan Administrasi Terpadu Kecamatan (PATEN) dalam meningkatkan pelayanan di Kecamatan Kluet Utara Kabupaten Aceh Selatan Provinsi Aceh?

2. Apa saja faktor-faktoryang memengaruhi dalam Implementasi Kebijakan Pelayanan Administrasi Terpadu Kecamatan (PATEN) di Kecamatan Kluet Utara Kabupaten Aceh Selatan Provinsi Aceh?

3. Bagaimana strategi yang perlu dilakukan dalam meningkatkan Implementasi Kebijakan Pelayanan Administrasi Terpadu Kecamatan (PATEN) di Kecamatan Kluet Utara Kabupaten Aceh Selatan Provinsi Aceh? 


\section{Tujuan Penelitian}

Berdasarkan maksud penelitian di atas, tujuan penelitian ini dirumuskan sebagai berikut.

1. Untuk mendeskripsikan dan menganalisis Implementasi Kebijakan Pelayanan Administrasi Terpadu Kecamatan (PATEN) di Kecamatan Kluet Utara Kabupaten Aceh Selatan Provinsi Aceh.

2. Untuk mendeskripsikan dan menganalisis faktor-faktor yang memengaruhi dalam Implementasi Kebijakan Pelayanan Administrasi Terpadu Kecamatan (PATEN) di Kecamatan Kluet Kabupaten Aceh Selatan Provinsi Aceh.

3. Untuk mendeskripsikan dan menganalisis strategi yang dilakukan dalam meningkatkan Implementasi Kebijakan Pelayanan Administrasi Terpadu Kecamatan (PATEN) di Kecamatan Kluet Utara Kabupaten Aceh Selatan Provinsi Aceh.

\section{KAJIAN PUSTAKA}

\section{Kebijakan Publik}

Kebijakan itu sendiri (public policy) adalah keputusan atau sejumlah atau serangkaian pilihan yang berhubungan satu sama lain yang dimaksudkan untuk mencapai tujuan. Menurut Lowi dalam Hamdi kebijakan publik dapat dibedakan atas tiga tipe, yaitu sebagai berikut.

\section{Kebijakan distributive}

2. Kebijakan redistributive

3. Kebijakan regulatory

\section{Implementasi Kebijakan}

Implementasi kebijakan akan lebih mudah bila dipahami menggunakan suatu model atau kerangka pemikiran tertentu. Suatu model yang mana akan memberikan gambaran kepada kita secara bulat lengkap mengenai sesuatu objek, situasi, atau proses. Komponen-komponen apa saja yang terdapat pada objek, situasi, atau proses tersebut. Bagaimana korelasi-korelasi antara komponen-komponen itu satu dengan yang lainnya.

\section{Teori Edwards III}

Edwards III menyatakan policy implementation as we have seen is the stage of policy making between the establishment of a policy such as the passage of a legislative act, the issuing of an executive order, the handling down of a judicial decision, or the promulgation of a regulatory rule and the consequences of the policy for the people whom it affects. Maksudnya implementasi kebijakan seperti yang kita lihat adalah tahap kebijakan membuat antara penetapan kebijakan seperti bagian dari tindakan legislatif, penerbitan perintah eksekutif, menyerahkan turun dari keputusan pengadilan, atau diundangkanya peraturan peraturan dan konsekuensi kebijakan bagi orang-orang yang terkena dampaknya.

Implementasi merupakan tindakantindakan yang dilakukan oleh pemerintah untuk mencapai tujuan tertentu yang telah ditetapkan dalam suatu keputusan kebijakan. Akan tetapi pemerintah dalam membuat kebijakan juga harus mengkaji terlebih dahulu apakah kebijakan tersebut dapat memberikan dampak yang baik atau malah sebaiknya bagi masyarakat yang mana bertujuan agar kebijakan tidak bertentangan apalagi sampai merugikan masyarakat.

George Edwards III mengemukakan beberapa hal yang dapat memengaruhi suatu keberhasilan Implementasi Kebijakan dengan Direct and Inderect Impact on Implementation, yaitu sebagai berikut.

1. Communication/komunikasi,

2. Resources/sumber daya,

3. Disposition/deposisi,

4. Bureaucratic Structure/ struktur birokrasi. 


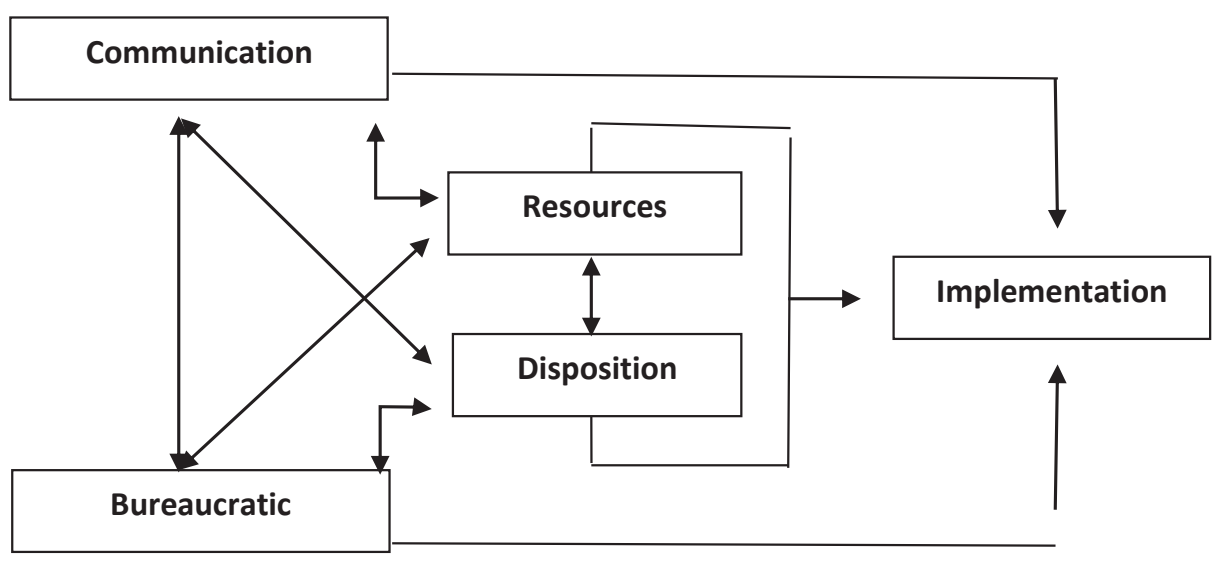

Gambar 1 Model Pendekatan Direct and Indirect Impact on Implementation

(Sumber: George III Edwards, (1980:148).

Keberhasilan suatu implementasi kebijakan yang dijelaskan oleh oleh Edwards III dalam buku Implementing Public Policy dipengaruhi oleh beberapa faktor di atas.

\section{Pelayanan Publik}

Pelayanan publik (public services) oleh birokrasi publik tadi adalah merupakan salah satu perwujudan dari fungsi aparatur negara sebagai abdi masyarakat di samping sebagai abdi negara. Pelayanan publik oleh birokrasi publik dimaksudkan untuk Menyejahterakan masyarakat (warga negara) dari suatu negara kesejahteraan (welfare state).

\section{Kualitas Pelayanan}

Tjiptono $^{1}$ menyatakan bahwa "Kualitas jasa atau kualitas pelayanan yang mendefinisikan sebagai kondisi dinamis yang berhubungan dengan produk, jasa, sumber daya manusia, proses dan lingkungan yang memenuhi atau melebihi harapan."Dengan demikian aspek penilaian terhadap kualitas suatu jasa, misalnya child care centre, bisa mencakup berbagai faktor yang saling terkait, di antaranya lokasi, biaya, status akreditasi, jumlah dan kualifikasi staf, reputasi child centre bersangkutan, desain kelas, dan

1 Fandy Tjiptono, 2005, Strategi Pemasaran Edisi-4, Penerbit Andi, Jakarta, Hlm. 110 arena bermain, variasi menu yang disajikan, jam operasi, sikap staf, perhatian personel terhadap kebutuhan dan perkembangan masing-masing anak, ketersediaan dan aksesibilitas terhadap fasilitas bermain dan belajar dan seterusnya.

\section{Fungsi Pemerintah}

Adam Smith mengemukakan bahwa pemerintah suatu negara mempunyai tiga fungsi pokok sebagai berikut.

1. Memelihara keamanan dan pertahanan dalam negeri.

2. Menyelenggarakan peradilan.

3. Menyediakan barang-barang yang tidak disediakan oleh pihak swasta.

\section{METODE PENELITIAN}

\section{Desain Penelitian}

Penelitian kualitatif merupakan kegiatan menganalisis perilaku manusia baik individu maupun kelompok untuk mengatasi permasalahan sosial baik dengan kata-kata, gambaran yang lengkap dan faktual dari segi konsep, perilaku dan persepsi. Berdasarkan penjelasan di atas, dapat dikonstruksikan bahwa tujuan penelitian kualitatif adalah untuk mengembangkan sebuah teori dari hasil perbandingan dengan teori-teori lain 
yang serupa, yang Peneliti anggap paling baik secara subjektif maupun objektif ${ }^{2}$. Penelitian ini menggunakan metode deskriptif.

Sejalan dengan hal tersebut, maka penelitian ini merupakan penelitian deskriptif dengan pendekatan kualitatif karena Peneliti ingin memahami dan mendeskripsikan atau menjelaskan fenomena dan gejala-gejala yang terjadi terhadap Implementasi Kebijakan Pelayanan Administrasi Terpadu Kecamatan di Kecamatan Kluet Utara Kabupaten Aceh Selatan Provinsi Aceh, termasuk upaya-upaya mengungkap dan mengatasi permasalahan dalam implementasi kebijakan tersebut.

\section{Teknik dan Instrumen Pengumpulan Data}

Penelitian ini menggunakan teknik pengumpulan data berupa metode wawancara, observasi, dan dokumentasi. Selanjutnya dalam penelitian ini sumber data diperoleh dari tiga sumber, yaitu person, place, dan paper.

\section{Informan dan Cara Menentukannya}

Informan dalam penelitian ini diambil secara Purposive Sampling. Berdasarkan teknik Purposive Sampling maka informan dalam penelitian ini adalah sebagai berikut.

Tabel 3 Daftar Informan

\begin{tabular}{|c|l|c|}
\hline No & Informan & $\begin{array}{c}\text { Jumlah } \\
\text { (Orang) }\end{array}$ \\
\hline 1. & Bupati Aceh Selatan & 1 \\
\hline 2. & Sekda Aceh Selatan: & 1 \\
\hline 3. & $\begin{array}{l}\text { Asisten Pemerintahan, } \\
\text { Keistimewaan Aceh dan } \\
\text { Kesejahteraan Aceh Selatan }\end{array}$ & 1 \\
\hline 5. & Kabag Tata Pemerintahan & 1 \\
\hline 6. & Kamat Kluet Utara & 1 \\
\hline 7. & Masyarakat & 1 \\
\hline & $\quad$ Jumlah & 7 \\
\hline
\end{tabular}

Sumber: Diolah peneliti, 2020

2 Khasan Effendy, Op. Cit., Hlm. 118.

\section{HASIL PENELITIAN}

Implementasi kebijakan Pelayanan Administrasi Terpadu Kecamatan di Kecamatan Kluet Utara Kabupaten Aceh Selatan Provinsi Aceh dilihat dari:

1. Produktivitas Sekretariat Kecamatan Kluet Utara Kabupaten Aceh Selatan dalam implementasi kebijakan Pelayanan Administrasi Terpadu Kecamatan di Kecamatan Kluet Utara Kabupaten Aceh Selatan Provinsi Aceh dapat dikatakan kurang maksimal. Hal ini dapat dilihat dari minimnya anggaran dan pencapaian targetyang belum sesuai dengan program yang telah ditetapkan sebelumnya. Selain itu juga kendala lain seperti masih kurangnya infrastruktur penunjang pelayanan sehingga kurang maksimalnya produktivitas pada saat proses pemberian pelayanan.

2. Kualitas layanan Sekretariat Kecamatan Kluet Utara Kabupaten Aceh Selatan dalam implementasi kebijakan Pelayanan Administrasi Terpadu Kecamatan di Kecamatan Kluet Utara Kabupaten Aceh Selatan Provinsi Aceh dirasa sudah cukup berkualitas. Hal ini dilihat dari Pemberian Informasi yang dilakukan Sekretariat Kecamatan Kluet Utara pada bagan informasi pada Sekretariat Kecamatan Kluet Utara. Namun hal tersebut dirasa masih kurang dikarenakan masih banyak masyarakat yang belum mengetahui informasi mengenai Pelayanan Administrasi Terpadu tersebut.

3. Responsivitas Sekretariat Kecamatan Kluet Utara Kabupaten Aceh Selatan dalam implementasi kebijakan Pelayanan Administrasi Terpadu Kecamatan di Kecamatan Kluet Utara Kabupaten Aceh Selatan Provinsi Aceh dapat dikatakan cukup baik. Hal ini dapat terlihat dari daya tangkap Sekretariat Kecamatan Kluet Utara Kabupaten Aceh Selatan yang langsung memproses 
jika ada permintaan pelayanan dari masyarakat.

4. Responsibilitas Sekretariat Kecamatan Kluet Utara Kabupaten Aceh Selatan dalam implementasi kebijakan Pelayanan Administrasi Terpadu Kecamatan di Kecamatan Kluet Utara Kabupaten Aceh Selatan Provinsi Aceh sudah cukup baik. Hal ini dapat dilihat dari tanggung jawab yang sudah terlaksana. Namun demikian masih terdapat kekurangan seperti belum terdapat sinkronisasi dengan aparatur desa dalam sinergitas pelayanan.

5. Akuntabilitas Sekretariat Kecamatan Kluet Utara Kabupaten Aceh Selatan dalam implementasi kebijakan Pelayanan Administrasi Terpadu Kecamatan di Kecamatan Kluet Utara Kabupaten Aceh Selatan Provinsi Aceh sudah cukup maksimal. Hal ini dapat dilihat dari Standar Operasional Prosedur (SOP) yang cukup jelas. Apabila pelayanan diharuskan dipungut biaya sudah terpampang jelas besarannya.

\section{SIMPULAN}

Berdasarkan hasil penelitian dan pembahasan, maka Penelti dapat menyimpulkan sebagai berikut.

Pertama, implementasi kebijakan pelayanan administrasi terpadu kecamatan di Kecamatan Kluet Utara Kabupaten Aceh Selatan Provinsi Aceh belum berjalan optimal. Berdasarkan indikator subtansi kebijakan, perilaku tugas pelaksana, interaksi jejaring kerja, partisipasi kelompok sasaran dan sumber daya disimpulkan bahwa Implementasi Kebijakan Pelayanan Administrasi Terpadu Kecamatan di Kecamatan Kluet Utara Kabupaten Aceh Selatan Provinsi Aceh belum sepenuhnya menjadi perhatian terutama ketersediaan sumber daya yang memadai yakni dalam hal kecukupan dana, ketersediaan pelaksanaan, kecukupan peralatan, ketersediaan informasi serta ketepatan teknologi. Partisipasi kelompok sasaran sangatlah penting dalam hal upaya peningkatan terhadap manfaat kegiatan juga perlu menjadi perhatian lebih serius untuk masa yang akan datang. Wawancara dengan menggunakan Teori Edwards III yang dapat diuraikan sebagai berikut.

a) Dimensi Komunikasi, belum optimalnya komunikasi sehingga informasi mengenai PATEN belum menyeluruh diterima oleh masyarakat Kluet Utara.

- Transmisi: PATEN telah disosialisasikan secara intens dan konsisten melalui beberapa cara. Namun belum semua masyarakat mengetahui kegunaan dari PATEN.

- Kejelasan: Belum ada sosialisasi mengenai manfaat dari PATEN yang tercantum dalam Peraturan Menteri dalam Negeri Nomor 4 Tahun 2010 yang dilimpahkan dalam keputusan Bupati Aceh Selatan Nomor 445 Tahun 2014 program PATEN.

- Kosistensi: Sosialisasi tentang PATEN telah dilakukan oleh pihak kecamatan namun memang belum mendapatkan respons yang positif di mata masyarakat.

b) Dimensi sumber daya, masih kurangnya kualitas dari pihak kecamatan dalam menjalankan pelayanan PATEN.

- Staf: Kualitas SDM pelaksana PATEN masih belum berkompeten,

- Informasi: mengenai cara pelayanan PATEN sudah disampaikan kepada staf layanan namun pada setiap tahunnya terjadi mutasi sifat di dalam kantor sehingga terdapat beberapa staf belum menerima informasi terutama staf yang baru yang belum mengikuti pelatihan.

- Wewenang: Wewenang yang dimiliki oleh aparatur kecamatan 
sudah melekat sejak dikeluarkannya keputusan Bupati Aceh Selatan Nomor 445 Tahun 2015.

- Fasilitas: peralatan dalam pelayanan PATEN di Kecamatan Kluet Utara masih kurang dalam memberikan pelayanan kepada masyarakat hal ini dapat memengaruhi aktivitas pelayanan yang diberikan kepada masyarakat.

c) Dimensi disposisi, proses rekruitmen belum berdasarkan kemampuan/ keterampilan yang dimiliki serta kurangnya insentif yang diberikan sehingga pegawai di kecamatan kurang termotivasi.

- Pengangkatan Birokrat: Proses rekruitmen admin pelaksana PATEN selama ini bukan dilakukan karena kemampuan, keahlian, kompetensi, ataupun keterampilan yang dimiliki. Loyalitas, konsistensi, integritas dan komitmen dari pihak kecamatan belum optimal dikarenakan kurangnya motivasi yang dimiliki.

- Insentif Aparatur: Dengan beban kerja yang dimiliki berbeda-beda mendapatkan insentif yang setiap 3 bulan sekali juga dirasa masih kurang dibandingkan dengan beban kerja yang diemban, dan faktor anggaran yang terbatas, karena anggaran yang baku untuk insentif sampai saat ini belum ada.

d) Dimensi Struktural birokrasi sudah baik ditandai dengan adanya SOP terkait PATEN dan pembagian tugas yang sudah jelas pada pegawai kecamatan

- SOP: adanya standar pelayanan prosedur PATEN di kecamatan terlihat di ruangan pelayanan.

- Fragmentasi: adanya penempatan dan pembagian tugas bagi pegawai kecamatan yang jelas sesuai dengan tugas dan fungsinya masing-masing.
Kedua, faktor-faktor yang memengaruhi implementasi kebijakan pelayanan administrasi terpadu kecamatan di Kecamatan Kluet Utara Kabupaten Aceh Selatan Provinsi Aceh adalah sebagai berikut.

a) Faktor Internal:

a. Adanya peraturan daerah Kabupaten Aceh Selatan yang mengatur Pelayanan Administrasi Terpadu Kecamatan di Kecamatan Kluet Utara.

b. Adanya komitmen Kecamatan Kluet Utara dalam pelaksanaan Pelayanan Administrasi Terpadu Kecamatan.

c. Terjalinnya koordinasi yang baik antartingkat pemerintahan terkait Pelayanan Administrasi Terpadu Kecamatan di Kecamatan Kluet Utara.

d. Terbatasnya sarana dan prasarana pendukung dalam Pelayanan Administrasi Terpadu Kecamatan di Kecamatan Kluet Utara.

e. Terbatasnya anggaran yang tersedia dalam Pelayanan Administrasi Terpadu Kecamatan di Kecamatan Kluet Utara.

f. Kompetensi dan jumlah sumber daya aparatur yang belum memadai dalam Pelayanan Administrasi Terpadu Kecamatan di Kecamatan Kluet Utara.

b) Faktor Eksternal:

a. Adanya dukungan dan kerja sama antarsektor pemerintahan dalam Pelayanan Administrasi Terpadu Kecamatan di Kecamatan Kluet Utara.

b. Adanya partisipasi perangkat desa dalam Pelayanan Administrasi Terpadu Kecamatan di Kecamatan Kluet Utara.

c. Adanya ketidaksukaan masyarakat dengan perangkat daerah, yaitu Camat Kluet Utara. 
d. Peningkatan sarana dan prasarana pelayanan sesuai dengan perkembangan zaman dan teknologi informasi.

e. Perkembangan dinamika teknologi informasi yang sangat cepat belum diimbangi dengan perubahan paradigma pelayanan.

f. Etika dan perilaku aparatur yang menunjukkan ketidakdisiplinan dan kurang ramah atau santun.

g. Letak pusat pemerintahan Kecamatan Kluet Utara yang jauh dari beberapa Desa.

Ketiga, strategi yang sebaiknya digunakan untuk meningkatkan keberhasilan Implementasi Kebijakan Pelayanan Administrasi Terpadu Kecamatan di Kecamatan Kluet Utara Kabupaten Aceh Selatan Provinsi Aceh oleh Sekretariat Kecamatan Kluet Utara adalah: meningkatkan komitmen pemerintah Kecamatan KluetUtara dalam melaksanakan Pelayanan Administrasi Terpadu Kecamatan, mengoptimalkan fungsi pegawai yang ada untuk melaksanakan tugas Pelayanan Administrasi Terpadu Kecamatan, merencanakan dan melakukan koordinasi secara berkala serta melaporkan permasalahan yang dihadapi di lapangan, meningkatkan sarana dan prasarana pelaksanaan Pelayanan Administrasi Terpadu Kecamatan, membuat rencana kebutuhan dan percepatan pelaksanaan Pelayanan Administrasi Terpadu Kecamatan, meningkatkan kapasitas aparatur melalui pelatihan pelaksanaan Pelayanan Administrasi Terpadu Kecamatan, memaksimalkan penggunaan teknologi dalam Pelayanan Administrasi Terpadu Kecamatan, memberikan teguran atau sanksi terhadap petugas yang tidak sesuai dengan SOP yang ditetapkan, melaksanakan program jemput bola untuk mengatasi permasalahan jauhnya letak pusat pemerintahan Kecamatan Kluet Utara dari beberapa desa, meningkatkan perangkat pendukung teknologi yang dibutuhkan dalam Pelayanan Administrasi Terpadu Kecamatan, meningkatkan kesejahteraan pelaksana Pelayanan Administrasi Terpadu Kecamatan dengan mengajukan peningkatan anggaran pada perencanaan anggaran tiap tahunnya, dan memberdayakan aparatur pelaksana Pelayanan Administrasi Terpadu Kecamatan secara maksimal serta melakukan studi banding.

\section{SARAN}

Berdasarkan simpulan di atas, maka Peneliti memberikan saran sebagai bahan evaluasi dan masukan terkait Implementasi Kebijakan Pelayanan Administrasi Terpadu Kecamatan di Kecamatan Kluet Utara Kabupaten Aceh Selatan Provinsi Aceh oleh Sekretariat Kecamatan Kluet Utara sebagai berikut.

\section{Saran Teoretis}

1. Untuk Peneliti selanjutnya yang menggunakan objek penelitian yang sama, diharapkan dapat menggunakan desain penelitian dan teknik analisis data yang berbeda agar lebih memperbanyak sumber-sumber dan referensi yang akurat terkait permasalahan yang diangkat.

2. Diharapkan juga bagi yang hendak melakukan penelitian implementasi kebijakan pelayanan administrasi terpadu kecamatan dapat melakukan kajian dari permasalahan dan sudut pandang yang berbeda atau menggunakan variabel penelitian yang berbeda, sehingga nantinya akan memperluas khazanah pengetahuan bagi Peneliti dan pembaca.

\section{Saran Praktis}

1. Berdasarkan karakteristik dimensi implementasi kebijakan yang dilihat dari indikator substansi kebijakan, perilaku tugas pelaksana, interaksi jejaring kerja, partisipasi kelompok sasaran 
dan sumber daya disarankan kepada Sekretariat Kecamatan Kluet Utara dapat lebih fokus kepada sumber daya yang memadai yakni dalam hal kecukupan dana, ketersediaan pelaksana, kecukupan peralatan, ketersediaan informasi serta ketepatan teknologi. Selain itu terus berupaya meningkatkan pelayanan sebagai peningkatan penerimaan terhadap manfaat kegiatan. Adapun dari isu strategis yang dapat di gunakan:

1) Isu sangat strategis, meliputi:

a. Meningkatkan komitmen Pemerintah Kecamatan dalam melaksanakan Pelayanan Administrasi Terpadu Kecamatan.

b. Mengoptimalkan fungsi pegawai yang ada untuk melaksanakan tugas Pelayanan Administrasi Terpadu Kecamatan.

c. Meningkatkan sarana dan prasarana pelaksanaan Pelayanan Administrasi Terpadu Kecamatan.

d. Melaksanakan program jemput bola untuk mengatasi permasalahan jauhnya letak pusat pemerintahan Kecamatan Kluet Utara dari beberapa Desa.

2) Isu cukup strategis, meliputi:

a. Membuat rencana kebutuhan dan percepatan pelaksanaan Pelayanan Administrasi Terpadu Kecamatan.

b. Meningkatkan kapasitas aparatur melalui pelatihan pelaksanaan Pelayanan Administrasi Terpadu Kecamatan.

c. Memaksimalkan penggunaan teknologi dalam Pelayanan Administrasi Terpadu Kecamatan.

d. Meningkatkan perangkatpendukung teknologi yang dibutuhkan dalam Pelayanan Administrasi Terpadu Kecamatan. e. Meningkatkan kesejahteraan pelaksana Pelayanan Administrasi Terpadu Kecamatan dengan mengajukan peningkatan anggaran pada perencanaan anggaran tiap tahunnya.

f. Memberdayakanaparaturpelaksana Pelayanan Administrasi Terpadu Kecamatan secara maksimal serta melakukan studi banding.

3) Isu bersifat operasional, meliputi:

a. Merencanakan dan melakukan koordinasi secara berkala serta melaporkan permasalahan yang dihadapi di lapangan.

b. Memberikan teguran atau sanksi terhadap petugas yang tidak sesuai dengan SOP yang ditetapkan.

2. Sekretariat Kecamatan Kluet Utara sebaiknya dapat melakukan studi banding dengan Sekretariat Kecamatan lain yang berada di dalam maupun luar Kabupaten Aceh Selatan yang sekiranya lebih baik dalam mengimplementasikan kebijakan pelayanan administrasi terpadu kecamatan agar dapat menjadi pembelajaran demi meningkatkan kualitas pelayanan pada Sekretariat Kecamatan Kluet Utara.

\section{DAFTAR PUSTAKA}

Assauri, Sofyan, 2003, Manajemen Pemasaran, Rajawali Pers, Jakarta.

Bastian, Indra, 2016, Strategi Manajemen Sektor Publik, Salemba Empat

Bryson, John M. 2008. Perencanaan Strategis Bagi Organisasi Sosial. Yogyakarta: Pustaka Pelajar.

Burhan Bungin. 2015. Penelitian Kualitatif, Kencana, Jakarta.

Dunn, William N, 1999, pengantar Analisis Kebijakan Publik, gajah Mada University Press, Yogyakarta.

Edwards III, 1980, implementation Public Policy, Congresional Quarterly Press. 
Effendy, Khasan, 2014, Memadukan Metode Kuantitatif dan Kualitatif, CV. Indra Prahasta, Bandung.

Hamdi, Muchlis. 2013. Kebijakan Publik Proses, Analisis dan Partisipasi, ghalia Indonesia, Jakarta.

Hamdi, MUchlis. 2014. Kebijakan Publik. Ghalia Indonesia. Bogor.

Hardiyansyah, 2011, kualitas Pelayanan Publik, Gava Media, Yogyakarta.

John W. Creswell, 2016, research Design, Pustaka Pelajar, Yogyakarta.

Juliansyah Noor, 2014, metodologi Penelitian, Pramedia Grup, Jakarta.

Luankali, Bernadus, 2007, analisis Kebijakan Publik dalam Proses Pengambilan Keputusan, Amelia Press, Jakarta.

M. Azis Firdaus. 2012. Metode Penelitian, Jelajah Nusantara, Tangerang.

Mangkoesoebroto, Guritno, 2000, Ekonomi Publik. BPFE. Yogyakarta.

Mazmanian, Daniel H, dan Paul A. Sabatier. 1983. Implementation and Public Policy, Harper Colins.

Moenir, 2011, manajemen Pelayanan Umum di Indonesia, PT. Bumi Aksara, Jakarta.

Moh. Nazir, Ph. D. 2014. Metode Penelitian, Bogor: Ghalia Indonesia.

Mulyadi, Deddy, 2015, studi Kebijakan Publik dan Pelayanan Publik, Alfabeta, Bandung.

Nugroho, Riant. 2011. Public Policy: Dinamika Kebijakan, Analisis Kebijakan, Manajemen Kebijakan. Jakarta: PT. Gramedia.

Patilima, Hamid, 2016, Metode Penelitian Kualitatif, Alfabeta, Bandung.

Rangkuti, Freddy, 2016, Teknik Membedah Kasus Bisnis Analisis SWOT, Gramedia Pustaka Utama

Rasyid, Ryaas, 1997, makna Pemerintahan: Tinjauan dari Segi Etika dan Kepemimpinan, pT. Yarsif Watampone, Jakarta.

Ratminto dan Atik Septi Winarsih, 2012, manajemen Pelayanan, pustaka Pelajar, Yogyakarta.
Ridwan HR. 2011. Hukum Administrasi Negara, Rajawali Pers, Jakarta.

Simangunsong, Fernandes, 2016, metodologi Penelitian Pemerintahan, Alfabeta, Bandung.

Sinambela, Lijak Poltak, 2010, reformasi Pelayanan Publik, bumi Aksara, Jakarta.

Situmorang, Chazali. 2016. Kebijakan Publik (Teori Analisis, implementasi dan evaluasi Kebijakan), SSDI, Depok.

Subarsono, A. G. 2005. Analisis Kebijakan Publik. Yogyakarta: pustaka Pelajar

Sutedi, Adrian, 2012, Hukum Pertambangan, Sinar Grafika, Jakarta.

Syafri, Wirman dan Setyoko, Israwan. 2010 Implementasi Kebijakan Publik dan Etika Profesi Pamong Praja, Alqaprint, Jatinangor, Sumedang.

Tachjan. 2006. Implementasi Kebijakan Publik, IPI, Bandung.

Tjiptono, Fandy, 2005, Strategi Pemasaran Edisi-4, Penerbit Andi, Jakarta

Wahab, Solichin. 2012. Analisis Kebijakan Publik dari Formulasi ke Penyusunan ModelModel Implementasi Kebijakan Publik, Bumi Aksara, Jakarta.

Wasistiono, Sadu dan Simangunsong, Fernandes. 2015 Metodologi Ilmu Pemerintahan, iPDN Press, Jatinangor.

Winarno, Budi. 2012. Kebijakan Publik Teori, Proses dan Studi Kasus. CAPS. Yogyakarta.

\section{Peraturan Perundang-Undangan}

Undang-Undang Nomor 9 Tahun 2015 tentang perubahan kedua dari UndangUndang Nomor 23 Tahun 2014 tentang Pemerintahan Daerah.

Undang-Undang Nomor 25 Tahun 2009 tentang Pelayanan Publik.

Peraturan Pemerintah Nomor 18 Tahun 2016 tentang Perangkat Daerah.

Peraturan Pemerintah Republik Indonesia Nomor 17 Tahun 2018 tentang Kecamatan.

Peraturan Menteri Dalam Negeri Nomor 4 Tahun 2010 tentang Pedoman Pelayanan Administrasi Terpadu Kecamatan. 
Keputusan Menteri Pendayagunaan Aparatur Negara Nomor 63/KEP/M. PAN/7/2003 tentang Pedoman Umum Penyelenggaraan Pelayanan Publik.

Keputusan Bupati Aceh Selatan No. 445 Tahun 2014 tanggal 7 Oktober tentang penetapan kecamatan sebagai penyelenggara PATEN dalam Kabupaten Aceh Selatan Tahun 2014
Peraturan Bupati Aceh Selatan Nomor 40 Tahun 2016 tentang Susunan Organisasi, Kedudukan, Tugas dan Fungsi serta Tata Kerja Kecamatan Kluet Utara Kabupaten Aceh Selatan.

\section{Lain-Lain}

https://www. Academia. Edu/9667828/ Kualitas_Pelayanan, diakses pada Sabtu, 18 Januari 2020, jam 22.45 